\title{
P2 -Los Rebeldes del pasado volverán: memoria y resistencia Guaymí
}

\section{The Rebels of the past will return: memory and resistance Guaymí}

\author{
Ana Sofía Solano Acuña*, María Teresa Mosquera \\ Universidad Nacional, Costa Rica* \\ ${ }^{2}$ Instituto de Estudios Interétnicos-USAC
}

$\begin{array}{ll} & * \text { Autor para correspondencia. } \\ \text { Resumen } & \text { Correo electrónico: sofisolano@gmail.com }\end{array}$

Resumen

$\mathrm{P}$

ara Panamá el final del período colombiano representó el inicio del proceso de constitución de un nuevo mapa sociopolítico, sembrando las bases para la naciente nación que arrastrará un esquema de relaciones polarizadas basadas en color de piel, lengua y pertenencia étnica. El sistema de explotación del indio vigente entre 1880-1903 se basó en las relaciones de clase, particularizadas por las relaciones interétnicas de dominación heredadas de la conquista y la colonia. El estudio del periodo de 18801903 deja como principal conclusión que tanto el pueblo guaimí de finales del siglo XIX como sus descendientes actuales son sociedades notablemente dinámicas, capaces de generar sus propios cambios y alianzas en razón de sus intereses colectivos. En este marco surgen las siguientes interrogantes ¿qué relevancia tiene la participación guaymí en la guerra de los mil días y el proceso de independencia de Panamá desde el movimiento indígena contemporáneo?, ¿en qué contextos surgen estos relatos?, ¿cómo se caracteriza la relación entre mito, historia y utopía?

Palabras clave: occidente de Panamá, etnicidad, memoria histórica, resistencia, utopía, interpretación histórica

Abstract

Gor Panama the end of the Colombian period represented the beginning of the process of constitution of a new sociopolitical 1 map, sowing the bases for the nascent nation that will drag a scheme of polarized relations based on skin color, language and ethnicity. The system of exploitation of the Indian in force between 1880-1903 was based on class relations, particularized by the interethnic relations of domination inherited from the conquest and the colony. The study of the 1880-1903 period leaves as its main conclusion that both the Guaimí people of the late nineteenth century and their current descendants are notably dynamic societies, capable of generating their own changes and alliances because of their collective interests. In this context, the following questions arise: what is the relevance of Guaymí participation in the war of a thousand days and the process of independence of Panama from the contemporary indigenous movement? In what contexts do these stories arise? How is the relationship characterized? between myth, history and utopia?

Keywords: west of Panama, ethnicity, historical memory, resistance, utopia, historical interpretation 


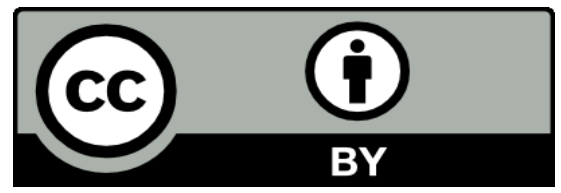

Este texto está protegido por una licencia CreativeCommons 4.0.

Usted es libre para compartir, copiar y redistribuir el material en cualquier medio o formato y adaptar el documento, remezclar, transformar y crear a partir del material para cualquier propósito, incluso comercialmente, siempre que cumpla la condición de atribución: usted debe reconocer el crédito de una obra de manera adecuada, proporcionar un enlace a la licencia, e indicar si se han realizado cambios. Puede hacerlo en cualquier forma razonable, pero no de forma tal que sugiera que tiene el apoyo del licenciante o lo recibe por el uso que hace. 